\title{
The stellar life and career of Rolf Wigand
}

\author{
Ian Maclnnes ${ }^{1}$
}

Received: 22 January 2021 / Accepted: 22 January 2021 / Published online: 11 February 2021

(C) Institute of Applied Informatics at University of Leipzig 2021

Our friend and colleague Rolf Wigand passed away on September 25, 2020, at the age of 76. He is survived by his wife Dianne, his brother Rainer, and many cousins. His son Andreas died earlier the same year.

After holding management positions in his native Germany, he moved to Texas Tech University where he was a track and field athlete and earned bachelor's and master's degrees. He later was awarded a Ph.D. from Michigan State University, continuing in the fields of business and communication. He began his professorial career in communication at Arizona State University in 1975 and moved in 1991 to Syracuse University's School of Information Studies. In 2002, he became the Maulden-Entergy Chair and Distinguished Professor of Information Science and Management at the University of Arkansas at Little Rock. After retiring in 2014 he moved back to Arizona and was affiliated with the Emeritus College at ASU. Throughout his career, he served as a visiting professor on four continents, held several administrative positions, and was a consultant to many businesses.

We know him best for his highly productive career as a researcher. He wrote or edited 21 books and over 500 research papers. Over 3500 articles cited his work in the past five years. He collaborated on publications with over a hundred scholars. His most cited works include editions of books in multiple languages co-authored with Arnold Picot and Ralf Reichwald entitled "Information, Organization and Management" and "Die grenzenlose Unternehmung" (The limitless enterprise), which apply economic theories of organization to new organizational forms, including markets. (Picot et al. 1996; Wigand et al. 1997) The Handelsblatt Management Bibliothek listed these editions as among the "75 best management books of all time" (Handelsblatt 2005).

Ian MacInnes

imacinne@syr.edu

1 School of Information Studies, Syracuse University, 224 Hinds Hall, Syracuse, NY 13244, USA
He played an early and important role in the development of electronic commerce research including a famous paper with Bob Benjamin in MIT Sloan Management Review "Electronic markets and virtual value chains on the information superhighway," which foresaw the development of electronic markets that would lower coordination and distribution costs for producers and retailers as well as eliminating some entirely (Benjamin and Wigand 1995). He expanded on these ideas in an article for The Information Society (Wigand 1997). You might say that his work anticipated the development of Amazon into a dominant electronic marketplace.

He also worked on case studies of the organizational aspects of industries such as home mortgages with Lynne Markus and Charles Steinfield (Markus et al. 2006) and real estate with Kevin Crowston and Steve Sawyer (Crowston et al. 2001). He sometimes examined people's interaction with technology, such as in 'Exploring web users' optimal flow experiences" with Hsiang Chen and Mike Nilan (Chen et al. 2000). He was also devoted to developing an educational curriculum for information systems (Gorgone et al. 2006). Further evidence of his interest in a variety of industries and related areas was his recent article on electronic health records implementation in Morocco (Parks et al. 2019). His co-author, Rashida Parks, was recently informed that the paper won the Forsyth Award from the American Medical Informatics Association (AMIA). She dedicated this award to Rolf.

In particular, he was deeply involved over decades with our journal, Electronic Markets, where he served as senior editor beginning in 2012. He was an early contributor to the journal with his paper "Electronic Commerce and Reduced Transaction Costs" (Wigand 1995). Rolf was selected to interview Tom Malone at MIT in a retrospective of an influential article on the replacement of hierarchies with markets (Malone et al. 1987). Electronic Markets later published Rolf's interview along with other analysis of the paper (Wigand 2011). Rolf's dedication to the field and the journal never ceased. EM published his most recent article "Whatever happened to disintermediation?" in his final year (Wigand 2020). He examined the effect of disintermediation on 
electronic markets through changes in transactions costs and their effect on the composition of value chains, including potential reintermediation. Maintaining consumer access to electronic markets will be an important concern for policymakers.

Rolf Wigand was also a good friend to many people, known for his dry sense of humor and, to his university colleagues, an office that looked to the uninitiated as disorganized but which some of us viewed as a museum of research. If anyone asked him for a paper, perhaps in a metres high pile on top of a long lost but still surviving cactus, he would immediately pull it out of the middle. On a personal level, I appreciate his advice early in my academic career and his introductions to people at events such as the Bled Electronic Commerce Conference. I also fondly remember Thanksgivings hosted by him and his wife Dianne before they left for Arkansas. I appreciated his annual family letters, which in recent years demonstrated that he had no intention of slowing down, as can be seen by his impressive list of publications since his retirement in 2014, including 19 that year and a book on virtual worlds in 2018 (Lakkaraju et al. 2018). Rolf and Dianne also kept themselves busy with their passion for travel. He said that "we are not ready for the rocking chair yet." It is our loss that his life was cut short this year. We will continue to benefit from his work.

\section{References}

Benjamin, R., \& Wigand, R. (1995). Electronic markets and virtual value chains on the information superhighway. MIT Sloan Management Review, 36(2), 62.

Chen, H., Wigand, R. T., \& Nilan, M. (2000). Exploring web users' optimal flow experiences. Information Technology \& People, 13(4), 263-281. https://doi.org/10.1108/09593840010359473

Crowston, K., Sawyer, S., \& Wigand, R. T. (2001). Investigating the interplay between structure and information and communications technology in the real estate industry. Information Technology \& People, 14(2), 163-183. https://doi.org/10.1108/ 09593840110695749
Gorgone, J. T., Gray, P., Stohr, E. A., Valacich, J. S., \& Wigand, R. T. (2006). MSIS 2006: Model curriculum and guidelines for graduate degree programs in information systems. Acm Sigcse Bulletin, 38(2), 121-196. https://doi.org/10.1145/1138403.1138448

Handelsblatt. (2005). 75 best management books of all time. In Handelsblatt Management Bibliothek, Vol. 1, pp. 188-192. Campus Verlag.

Lakkaraju, K., Sukthankar, G., \& Wigand, R. T. (2018). Social interactions in virtual worlds: An interdisciplinary perspective. Cambridge University Press.

Malone, T. W., Yates, J., \& Benjamin, R. I. (1987). Electronic markets and electronic hierarchies. Communications of the ACM, 30(6), 484-497. https://doi.org/10.1145/214762.214766.

Markus, M. L., Steinfield, C. W., \& Wigand, R. T. (2006). Industry-wide information systems standardization as collective action: The case of the U.S. residential mortgage industry. MIS Quarterly, 30, 439-465. https://doi.org/10.2307/25148768 .

Parks, R., Wigand, R. T., Othmani, M. B., Serhier, Z., \& Bouhaddou, O. (2019). Electronic health records implementation in Morocco: Challenges of silo efforts and recommendations for improvements. International Journal of Medical Informatics, 129, 430-437. https:// doi.org/10.1016/j.ijmedinf.2019.05.026 .

Picot, A., Reichwald, R., \& Wigand, R. T. (1996). Die grenzenlose Unternehmung: Information, organisation und management [first, second, third, fourth and fifth editions]. Gabler Verlag.

Wigand, R. T. (1995). Electronic commerce reduced transaction costs. Electronic Markets, 5(3), 1-5.

Wigand, R. T. (1997). Electronic commerce: Definition, theory, and context. The Information Society, 13(1), 1-16. https://doi.org/10.1080/ 019722497129241

Wigand, R. T. (2011). 20 years of research in electronic markets and networked business: An interview with Thomas Malone. Electronic Markets, 21(1), 5-17. https://oi.org/10.1007/s12525011-0053-3 .

Wigand, R. T. (2020). Whatever happened to disintermediation? Electronic Markets, 30, 39-47. https://doi.org/10.1007/s12525019-00389-0

Wigand, R. T., Picot, A., \& Reichwald, R. (1997). Information, organization and management: Expanding markets and corporate boundaries. Wiley.

Publisher's note Springer Nature remains neutral with regard to jurisdictional claims in published maps and institutional affiliations. 